\title{
First report of Iranian National nosocomial infectionsurveillance system software
}

\author{
M Askarian ${ }^{1 *}$, H Mahmoudi ${ }^{1}$, O Assadian ${ }^{2}$ \\ From International Conference on Prevention \& Infection Control (ICPIC 2011) \\ Geneva, Switzerland. 29 June - 2 July 2011
}

\section{Introduction / objectives}

Nosocomial infections are one of the most important health problems particularly in developing countries, because these infections cause high mortality and morbidity and have many economic loss consequences. To date however most surveillance studies have been conducted in most of developed countries, only a very few have been accomplished in Iran. The aim of this study is to determine the incidence of nosocomial infections in a big university hospital of Shiraz.

\section{Methods}

The study was conducted prospectively through six months from $21^{\text {st }}$ March up to $22^{\text {nd }}$ September 2006 in a 374 bed educational hospital. All patients admitted during this period were included in the study and examined everyday for detecting four types of nosocomial infections: surgical site infection, urinary tract infection, pneumonia and blood stream infections. Centres for Disease Control and Prevention National Nosocomial Infection Surveillance system criteria were applied.

\section{Results}

4013 patients were admitted in hospital. Overall infection rate was $2.45 \%$ and UTI, SSI, BSI and pneumonia rates were $1.07 \%, 0.72 \%, 0.32 \%$ and $0.32 \%$ respectively.

\section{Conclusion}

To reduce nosocomial infections the first step is organizing a standard surveillance system, accurate and on time diagnosis of these infections and implying the infection preventing and control programs.

Community Medicine, Shiraz University of Medical Sciences, Shiraz, Iran, Islamic Republic Of

Full list of author information is available at the end of the article

\section{Disclosure of interest}

None declared.

\section{Author details}

'Community Medicine, Shiraz University of Medical Sciences, Shiraz, Iran, Islamic Republic Of. ${ }^{2}$ University Hospital Vienna, Clinical Institute for Hygiene and Medical Microbiology Medical University Vienna, Vienna, Austria.

Published: 29 June 2011

\section{doi:10.1186/1753-6561-5-S6-P231}

Cite this article as: Askarian et al:: First report of Iranian National nosocomial infectionsurveillance system software. BMC Proceedings 2011 5(Suppl 6):P231.
Submit your next manuscript to BioMed Central and take full advantage of:

- Convenient online submission

- Thorough peer review

- No space constraints or color figure charges

- Immediate publication on acceptance

- Inclusion in PubMed, CAS, Scopus and Google Scholar

- Research which is freely available for redistribution
() Biomed Central 